\title{
Haematological and serum biochemical reference intervals of juvenile African bonytongue fish (Heterotis niloticus. Cuvier, 1829) sampled from the river benue, Nigeria
}

Adeyemo Bolade, Enefe Ndidi

Department of Physiology and Biochemistry, Faculty of Veterinary Medicine, University of Abuja, Nigeria

\section{ARTICLE HISTORY}

\section{Received: 05.01.2021}

Revised: 09.03.2021

Accepted: 02.04.2021

Correspondence to Adeyemo Bolade; Tel:+2348038049383;E-mail:

bolade.adeyemo@uniabuja.edu.ng

\section{ABSTRACT}

\begin{abstract}
Objective: Based on the potential clinical and management significance of selected hematological and serum biochemistry parameters, study aimed to establish the hematological and serum biochemistry reference ranges for juvenile Heterotis niloticus (African bonytongue fish) a fish with significant aquaculture potential in Africa.

Design and procedure: Hematology and serum biochemical reference ranges were determined in blood and serum samples obtained from 243 healthy juvenile Heterotis niloticus sampled from three locations along the Benue River and its adjoining wetlands. The reference ranges were obtained using the Shapiro Wilk test and the guidelines of the national committee for clinical laboratory standards.

Results: Hematological reference ranges are; packed cell volume $19-27 \%$; hemoglobin concentration 3.1- $6.4 \mathrm{~g} / \mathrm{dL}$; total erythrocytes count $1.59 \times 10^{6}-2.92 \times 10^{6} \mu / \mathrm{L}$; total leucocytes counts $4.97 \times 10^{3}-5.40 \times$ $10^{3} \mathrm{\mu} / \mathrm{L}$; mean corpuscular volume $113.7-218.7 \mathrm{fL}$; mean corpuscular haemoglobin $25.06-28.85 \mathrm{pg}$; mean corpuscular hemoglobin concentration $12.61-20.27 \mathrm{~g} / \mathrm{dL}$. Serum biochemical reference ranges are; serum glucose, $51.0-89.50 \mathrm{mg} / \mathrm{dL}$; total protein $56.5-79.50 \mathrm{~g} / \mathrm{L}$; globulin $11.5-15.50 \mathrm{~g} / \mathrm{L}$; albumin $32.88-69.35$ $\mathrm{g} / \mathrm{L}$; aspartate amino transferase $79.2-98.3 \mathrm{U} / \mathrm{L}$; alanine amino transferase $24.78-46.0 \mathrm{U} / \mathrm{L}$. Alkaline phosphatase $28.75-57.25 \mathrm{U} / \mathrm{L}$; creatinine $51.0-80.0 \mathrm{~g} / \mathrm{L}$; urea $13.1-17.10 \mathrm{mg} / \mathrm{dL}$ and uric acid 1.90 $2.30 \mathrm{mg} / \mathrm{dL}$.

Conclusion and Clinical Relevance: These data will provide clinically useful information for the diagnosis, treatment and prognostication of intervention and or outcomes in the culture and or zootechnical management of Heterotis niloticus in natural water bodies.
\end{abstract}

Keywords: Osteoglossiform fish, African bonytongue fish, Haematological, Serum biochemical, Reference ranges.

\section{INTRODUCTION}

Fish is an important source of protein, rich in essential amino acids and omega $\mathrm{H} 3$ fatty acids [1]. In rural Africa, people depend on fish to meet their protein requirements [2] and for this purpose a vast variety of fish species are harvested from rivers, lakes and their adjoining wet lands $[3,4]$. The African bonnytongue fish (Heterotis niloticus, Curvier 1829) is amongst the most highly valued fresh water fish in the West Africa inland fisheries $[5,6]$.

Related to the Arapaimidae of the Amazons $[7,8] . \mathrm{H}$. niloticus is widely distributed in the tropical rivers and freshwater lakes of West and Central Africa [9, 10]. H. niloticus is noted to have a high growth rate [11] and has been reported to attain $6 \mathrm{~kg}$ body weight, $900 \mathrm{~mm}$ standard length [12]. Due to its high degree of behavioral food plasticity, this fish has been reported to occupy and colonize various freshwater habitats [3, 13]. In nature $H$. niloticus is an omnivore feeding on a wide variety of food among which are aquatic invertebrates, aquatic plants, seeds and detritus $[1,11]$. Under culture conditions, $H$. niloticus is reported to attain a body weight of $7.0 \mathrm{~kg}$ in 11 months [9]. Therefore, $H$. niloticus has been proposed as a candidate fish species for the diversification and expansion of aquaculture production in Nigeria (and elsewhere in West Africa).

Hematological and serum biochemical parameters are key clinical tools required for the diagnosis and prognostication of health statuses under culture or natural conditions $[14,15]$. Hematological assessment is a rapid approach for the determination of the fish homeostasis, while of the fish while serum biochemical assessments provides information on physio-pathological changes in the organs and or systems of the fish [16]. However, for these tools to be effective there is a need to have a reliable set of reference values (obtained from healthy specimens) upon which results can be compared [17, 18].

The hematological reference interval for human populations is defined as the mean \pm 1.96 SD of the mean for a normally distributed data and or values at 2.5 and 97.5 percentiles for non-normally distributed values [19]. TavareasDias and Moraes defined the reference interval by the upper and lower limits of $75^{\text {th }}$ and $25^{\text {th }}$ percentile values obtained from a reference population that meets certain set criteria such 
as age, sex and absence of disease conditions [16]. Some reports have advised the substitution of the term 'reference', 'standard' and or 'normal' interval with 'physiological range' (a term with a wider limit of normality) when dealing with aquatic organisms [20]. These reports further opined that the substitution is necessitated by the poikilothermy exhibited by fishes and the strong dependence of the physiological/metabolic processes of aquatic organisms on extrinsic factors such as physico-chemical parameters of the water.

The hematological and serum biochemistry reference intervals have been established for some fish species under intensive culture and a few others under natural conditions; including Cyprinus capio [15], Rhamdia quelen [21], Ictalurus punctatus [16], Synodontis membrananacea [22], Clarias gariepinius [14]. As the culture of $H$. niloticus continues to increase and intensify, it is expected that there would be an increase in the incidence of disease and or nutritional problems in the farming of this fish species $[23,24]$. A situation that may necessitate veterinary clinical interventions [25]; hence the need to have a robust set of haematological and serum biochemical reference data upon which such diagnostic, therapeutic and or prognostic decisions may be evaluated [25]. Asides from the reports of $[1,26,27]$ that dwelled essentially on some hematology of $H$. niloticus, there is a paucity of information on the hematology and serum biochemical ranges of $H$. niloticus. Hence, due to the increasing importance of $H$. niloticus to aquaculture and freshwater fisheries management in West Africa, there is a crucial need to determine the hematological and serum biochemistry reference interval for this fish. In this report, we present important clinical pathology reference data for juvenile African bonytongue fish.

\section{MATERIALS AND METHODS}

Two hundred and forty three juvenile $H$. niloticus fish were used for this study.

\subsection{Fish and sample preparations}

Fish and sample preparations: Fish were sampled bimonthly between July 2018 and August 2019 from the Lower Benue River basin using seine nets. 128 juvenile $H$. niloticus were sampled from Site 1 (Benue River $7^{0} 44^{\prime} \mathrm{N}, 8^{0} 32^{\prime} \mathrm{E}$ ); 63 juvenile $H$. niloticus sampled from Site $2\left(8^{0} 26^{\prime} \mathrm{N}, 10^{\circ} 05^{\prime} \mathrm{E}\right)$ at the discharge of Wase river into the Benue River and 52 juvenile $H$. niloticus fish from sampling Site $3\left(7^{0} 59^{\prime} \mathrm{N}, 7^{0} 55^{\prime} \mathrm{E}\right)$ at the Discharge of the Mada river into Benue River (Figure 1).

To ensure collected fishes were analyzed under approximately the same environmental conditions, all fish samples were collected in a single catch at same time of the day during sampling trips. Environmental conditions in all sampling sites were deemed to be similar (depth > $2 \mathrm{~m}$ and < $5 \mathrm{~m}$; water temperature 28.84 to $29.16{ }^{\circ} \mathrm{C}$ ). An average of six water samples were obtained per site. Captured fish appeared healthy (weighed $405-530 \mathrm{~g}$, total length $35.5-61.0 \mathrm{~cm}$ and swam aggressively). Following capture, fish were sedated in buffered MS 222 (250 mg/L) for 10 to 15 minutes as described [28] and screened for the presence of lacerations, parasites and disease-causing organisms following the methods of [25] and [29]. Then, $4 \mathrm{ml}$ of blood was collected per fish (using a $5 \mathrm{ml}$ syringe and 19-gauge needles) via caudal vein puncture. The collected blood was shared into two aliquots. The first aliquot was place in tubes (previously moistened with $10 \%$ EDTA solution) and utilized for hematological evaluations and the other portion were placed into clean narrow bored glass test tube (where they were allowed to clot for about an hour at room temperature). The test tubes containing the clotted blood were then centrifuge at $18187 \times \mathrm{g}$ and the clear serum eluted (and stored at $-20^{\circ} \mathrm{C}$ ) for use in serum biochemical evaluations. Due to the absence of distinct external genitalia, the sampled fishes could not be separated into distinct sexes.

\subsection{Water Analysis}

Water samples were obtained from the sampling sites at about the same periods of the day and analyzed according to the methods of Boyd and Tucker [30]. Temperature, dissolve oxygen, $\mathrm{pH}$ and conductivity were measured in triplicate samples. Values obtained for water quality parameters are temperature: $29.15 \pm 0.61 ; 10.56 \pm 0.15 \mathrm{mg} / \mathrm{dL}: \mathrm{pH} ; 8.05 \pm 0.01$ and conductivity; $497.7 \pm 0.9 \mu \mathrm{S} / \mathrm{cm}$ (these values are within the acceptable water quality parameter ranges in freshwater fishes).

\subsection{Hematological evaluations}

Erythrocytes and leucocytes enumerations was achieved by the aid of the Neubaeur counting chamber using the Natt and Herrick and the white blood cell dilution fluid respectively according the methods Campbell [31]. The number of cells obtained from the erythrocytes enumerations were multiplied by 10,000 to obtain the total number of erythrocytes per microliter of blood. And the number of leucocytes obtained from the leucocytes enumerations were multiplied by 50 to obtain the total leucocytes count per microliter of blood [16].

Hemoglobin concentration was determined spectrophotometrically using the cyanomethaemoglobin method [31]. Packed cell volume was determined by the micro hematocrit method [32]. And the erythrocytic indices were determined mathematically, as described by Campbell [33].

\subsection{Serum biochemical analysis}

Clinical biochemistry analysis was performed to obtain serum concentrations of glucose, total protein, albumin, urea, 
uric acid, creatinine kinase and serum activities of alkaline phosphatase and the transaminases on the serum obtained from the blood samples using a multichannel automatic chemistry analyzer (Chemwell 4800, Awareness Technology FL. USA) and Dialab clinical chemistry colorimetric diagnostic kits (Dialab Produktion Astria) following the manufacturer's instructions. Globulin was obtained mathematical by the deduction of values obtained for albumin from values obtained for serum total protein [23].

\subsection{Data Analysis}

Results obtained for the hematological and serum biochemistry assessments were tested for normality using the Shapiro Wilk test. The measurements of central tendencies (mean, mode, median) and dispersion (standard error, range, interquartile range) and other point estimates $\left(1^{\text {st }}\right.$ and $3^{\text {rd }}$ quartiles) were calculated for all parameters. Statistical evaluations were carried out on non-normally distributed parameters using their corresponding non-parametric methods [34]. Reference intervals were defined according to the guidelines for the National Committee for Clinical Laboratory Standards [35] and [36]; as values between the first and the third quartiles. Data analysis was performed using SPSS version 20 software (SPSS Inc. Chicago IL, USA).

\section{RESULTS}

\subsection{Hematology}

Results obtained for the hematological assessments of juvenile Heterotis niloticus collected from sampling site 1 are as presented in Table 1. It shows the packed cell volume (PCV) in juvenile Heterotis niloticus ranged between 17.0 and $31.0 \%$ with an interquartile range of $8.0 \%$. The erythrocytes count ranged between $1.59 \times 10^{6}$ and $3.04 \times 10^{6} \mu /$ L of blood with an interquartile range of $1.59 \times 10^{6} \mu / \mathrm{L}$. The derived erythrocytic indices for juvenile Heterotis niloticus are as follows; the mean corpuscular volume (MCV) ranged between $102.1 \mathrm{fL}$ and 265.6 $\mathrm{fL}$. In addition, the mean corpuscular hemoglobin concentration ( $\mathrm{MCHC}$ ) ranged between $11.77 \mathrm{~g} / \mathrm{dL}$ and $23.13 \mathrm{~g} / \mathrm{dL}$ with an interquartile range of $7.66 \mathrm{~g} / \mathrm{dL}$.

Table 1. Hematological reference interval of juvenile Heterotis niloticus sampled from site 1.

\begin{tabular}{|c|c|c|c|c|c|c|c|c|c|}
\hline Parameters & Mean & $\begin{array}{l}\text { Standard } \\
\text { Deviation }\end{array}$ & Mode & Range & IQR & $1^{\text {st }}$ Quantile & $3^{\text {rd }}$ Quantile & Min & Max \\
\hline PCV (\%) & 23.19 & 4.580 & 17.00 & 14.00 & 8.00 & 19.00 & 27.00 & 17.00 & 31.00 \\
\hline $\mathrm{HB}(\mathrm{g} / \mathrm{dL})$ & 4.606 & 1.683 & 6.80 & 5.40 & 3.10 & 3.10 & 6.40 & 2.00 & 7.40 \\
\hline $\operatorname{RBC}\left(10^{6} \mu / L\right)$ & 2.12 & 0.75 & $\begin{array}{l}0.64 \\
1.49 \\
1.74\end{array}$ & 2.57 & 1.32 & 1.59 & 2.92 & 0.64 & 3.04 \\
\hline WBC $\left(10^{3} \mu / L\right)$ & 5.181 & 0.264 & 5.07 & 0.85 & 0.435 & 4.97 & 5.40 & 4.80 & 5.65 \\
\hline $\operatorname{MCV}(f L)$ & 171.2 & 55.45 & $\begin{array}{l}102.7 \\
184.7 \\
265.6\end{array}$ & 163.5 & 104.9 & 113.7 & 218.7 & 102.1 & 265.6 \\
\hline $\mathrm{MCH}(\mathrm{Pg})$ & 27.15 & 2.15 & $\begin{array}{l}26.04 \\
26.66 \\
27.04\end{array}$ & 7.21 & 3.79 & 25.06 & 28.85 & 23.7 & 30.91 \\
\hline $\mathrm{MCHC}(\mathrm{g} / \mathrm{dL})$ & 17.08 & 3.82 & 23.13 & 11.36 & 7.66 & 12.61 & 20.27 & 11.77 & 23.13 \\
\hline
\end{tabular}

$I Q R$, inter quartile range; Min, minimum value; Max, maximum value; $P C V$, packed cell volume; $H B$, hemoglobin concentration; $R B C$, total erythrocytes count; WBC, total leucocytes count; $\mathrm{MCV}$, mean corpuscular volume; $\mathrm{MCH}$, mean corpuscular hemoglobin; MCHC, mean corpuscular hemoglobin concentration.

Table 2 shows the results obtained for serum biochemistry assessments of $H$. niloticus sampled from sampling site 1 . It shows the mean serum glucose concentration to be 71.94 $\mathrm{mg} / \mathrm{dL}$ with an inter quartile range of $38.5 \mathrm{mg} / \mathrm{dL}$ and a minimum and maximum serum glucose concentration of 35.0 and $109.0 \mathrm{mg} / \mathrm{dL}$ respectively. Further, the serum total protein concentration of $H$. niloticus sampled from Site 1 had a mean value of $68.87 \mathrm{~g} / \mathrm{L}$ with the first and second quartile values of 56.0 and $79.5 \mathrm{~g} / \mathrm{L}$ respectively. Table 2 also shows the mean serum aspartate amino transferase (AST) activity to be 88.27
$\mathrm{U} / \mathrm{L}$ with a range of $52.1 \mathrm{U} / \mathrm{L}$ and an interquartile range of 19.1 $\mathrm{U} / \mathrm{L}$. The mean serum urea concentration for fish sampled from this site is $2.15 \mathrm{mg} / \mathrm{dL}$ with minimum and maximum serum urea concentrations of 1.8 and $2.7 \mathrm{mg} / \mathrm{dL}$ respectively.

Table 3 depicts results obtained for the hematological assessments of juvenile Heterotis niloticus obtained from sampling sites 2 and 3 . It shows the range for the packed cell volume is $15.0 \%$ and the minimum and maximum packed cell volume is $18.0 \%$ and $33.0 \%$ respectively. 
Table 2. Serum biochemistry interval of juvenile Heterotis niloticus sampled from site 1.

\begin{tabular}{|c|c|c|c|c|c|c|c|c|c|}
\hline Parameters & Mean & $\begin{array}{l}\text { Standard } \\
\text { Deviation }\end{array}$ & Mode & Range & IQR & $1^{\text {st }}$ Quantile & $3^{\text {rd }}$ Quantile & Min & Max \\
\hline Glucose (mg/dL) & 71.94 & 19.84 & 49.00 & 84.00 & 38.50 & 51.00 & 89.50 & 35.00 & 109.0 \\
\hline Total Protein (g/L) & 68.87 & 18.52 & 100.0 & 64.00 & 23.00 & 56.50 & 79.50 & 39.00 & 103.0 \\
\hline Globulin (g/L) & 13.25 & 2.058 & 16.00 & 7.10 & 3.65 & 11.50 & 15.50 & 9.00 & 16.10 \\
\hline Albumin (g/L) & 51.35 & 20.49 & $\begin{array}{l}23.00 \\
86.8\end{array}$ & 63.80 & 36.48 & 32.88 & 69.35 & 23.00 & 86.8 \\
\hline AST (U/L) & 88.27 & 1.873 & $\begin{array}{l}93.00 \\
100.0\end{array}$ & 52.1 & 19.1 & 79.2 & 98.3 & 51.9 & 104.0 \\
\hline ALT (U/L) & 33.99 & 12.07 & 50.00 & 39.00 & 21.23 & 24.78 & 46.0 & 14.00 & 53.00 \\
\hline ALP (U/L) & 42.85 & 16.79 & 54.00 & 56.00 & 28.50 & 28.75 & 57.25 & 10.00 & 66.00 \\
\hline CRT ( $\mu \mathrm{mol} / \mathrm{L})$ & 65.75 & 13.87 & $\begin{array}{l}43.0 \\
80.0 \\
81.0\end{array}$ & 46.00 & 29.00 & 51.00 & 80.00 & 43.00 & 89.00 \\
\hline UREA (mg/dL) & 14.91 & 2.01 & $\begin{array}{l}12.6 \\
13.1\end{array}$ & 6.00 & 4.00 & 13.10 & 17.10 & 12.00 & 18.00 \\
\hline $\mathrm{UA}(\mathrm{mg} / \mathrm{dL})$ & 2.151 & 0.269 & 1.90 & 0.90 & 0.40 & 1.90 & 2.300 & 1.800 & 2.700 \\
\hline
\end{tabular}

IQR, inter quartile range; Min, minimum value; Max, maximum value; AST, aspartate aminotransferase; ALT, alanine aminotransferase; ALP, alkaline phosphatase; CRT, creatinine; UA, uric acid.

Table 3 also shows the range for erythrocyte counts to be $2.61 \times 10^{6} \mu / L$ of blood and the mean leucocytes counts to be $5.26 \times 10^{3} \mathrm{\mu} / \mathrm{L}$ of blood with an inter quartile range of $0.35 \times 10^{3}$ $\mu / L$ of blood. The range for the mean corpuscular volume is $163.5 \mathrm{fL}$ with a first quartile and second quartile values of 102.75 and $205.65 \mathrm{fL}$ respectively.

\subsection{Serum biochemistry}

Serum biochemistry assessment of $\mathrm{H}$. niloticus sampled from sampling site 1 are presented in Table 2 . It shows the mean serum glucose concentration to be $71.94 \mathrm{mg} / \mathrm{dL}$ with an inter quartile range of $38.5 \mathrm{mg} / \mathrm{dL}$ and a minimum and maximum serum glucose concentration of 35.0 and 109.0 $\mathrm{mg} / \mathrm{dL}$ respectively. Further, the serum total protein concentration of $\mathrm{H}$. niloticus sampled from Site 1 had a mean.

Value of $68.87 \mathrm{~g} / \mathrm{L}$ with the first and second quartile values of 56.0 and $79.5 \mathrm{~g} / \mathrm{L}$ respectively. Table 2 also shows the mean serum aspartate amino transferase (AST) activity to be 88.27 $\mathrm{U} / \mathrm{L}$ with a range of $52.1 \mathrm{U} / \mathrm{L}$ and an interquartile range of 19.1 $\mathrm{U} / \mathrm{L}$. The mean serum urea concentration for fish sampled from this site is $2.15 \mathrm{mg} / \mathrm{dL}$ with minimum and maximum serum urea concentrations of 1.8 and $2.7 \mathrm{mg} / \mathrm{dL}$ respectively. The results obtained for the serum biochemical assessments of fish sampled from sites 2 and 3 are as shown in Table 4 . It shows the mean serum glucose concentration to be $80.44 \mathrm{mg} / \mathrm{dL}$ with a minimum and maximum value of $44.0 \mathrm{mg} / \mathrm{dL}$ and $101.0 \mathrm{mg} / \mathrm{dL}$ respectively.

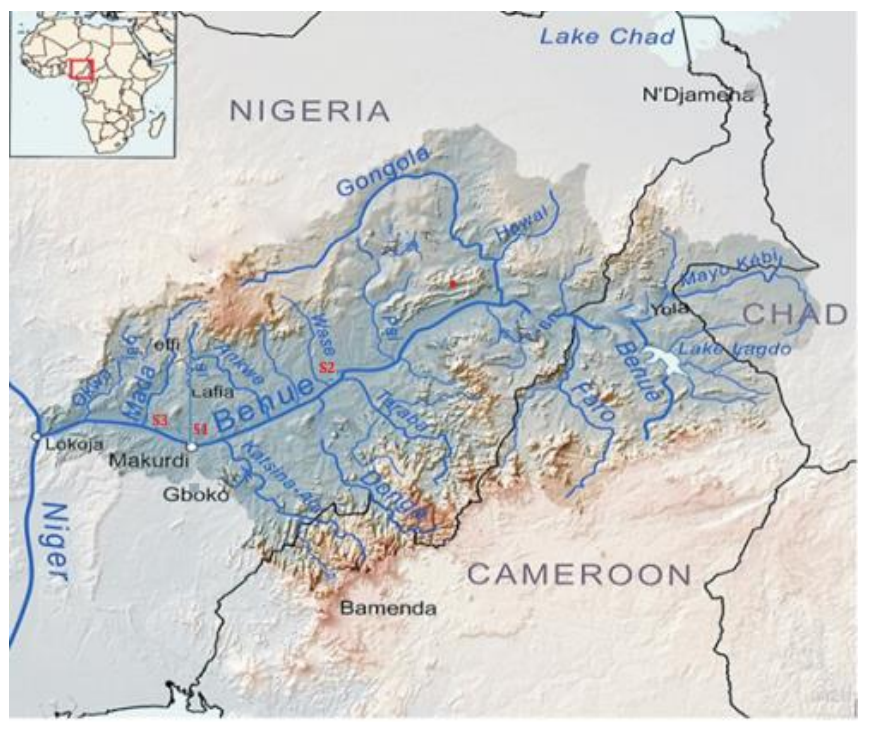

Figure 1. Benue River Basin showing sampling sites along the Benue River basin. Sampling site 1 (S1) $\left(7^{0} 44^{\prime} \mathrm{N}, 8^{0} 32^{\prime} \mathrm{E}\right)$ Benue River. Sampling site 2 (S2) $\left(8^{0} 26^{\prime} \mathrm{N}\right.$ $10^{\circ} 05^{\prime} \mathrm{E}$ ) Discharge of Wase river into the Benue River and Sampling site 3 (S3) $\left(7^{0} 59^{\prime} \mathrm{N}, 7^{0} 55^{\prime} \mathrm{E}\right)$ Discharge of the Mada river into Benue River. Source google maps 2019. 
Table 3. Hematological Reference interval of juvenile Heterotis niloticus sampled from site 2 and site 3.

\begin{tabular}{|c|c|c|c|c|c|c|c|c|c|}
\hline Parameters & Mean & $\begin{array}{l}\text { Standard } \\
\text { Deviation }\end{array}$ & Mode & Range & IQR & $1^{\text {st }}$ Quantile & $3^{\text {rd }}$ Quantile & Min & Max \\
\hline PCV (\%) & 26.62 & 4.66 & 27.00 & 15.00 & 5.50 & 24.0 & 29.50 & 18.00 & 33.00 \\
\hline$H B(g / d L)$ & 4.61 & 1.91 & $\begin{array}{l}2.80 \\
3.40 \\
3.60\end{array}$ & 5.10 & 4.05 & 3.0 & 7.05 & 2.30 & 7.40 \\
\hline $\operatorname{RBC}\left(10^{6} \mu / L\right)$ & 2.51 & 0.60 & 2.00 & 2.61 & 0.80 & 2.01 & 2.81 & 1.49 & 4.10 \\
\hline WBC $\left(10^{3} \mu / L\right)$ & 5.26 & 0.34 & $\begin{array}{l}5.07 \\
5.40\end{array}$ & 1.43 & 0.35 & 5.05 & 5.40 & 4.88 & 6.31 \\
\hline MCV (fL) & 152.6 & 63.04 & 256.6 & 163.5 & 102.9 & 102.8 & 205.7 & 102.1 & 265.6 \\
\hline $\mathrm{MCH}(\mathrm{Pg})$ & 16.52 & 2.862 & $\begin{array}{l}12.53 \\
12.68\end{array}$ & 7.66 & 6.72 & 13.32 & 20.04 & 12.53 & 20.91 \\
\hline $\mathrm{MCHC}(\mathrm{g} / \mathrm{dL})$ & 27.23 & 1.786 & $\begin{array}{l}23.95 \\
24.68\end{array}$ & 6.95 & 3.30 & 25.04 & 28.34 & 23.95 & 30.90 \\
\hline
\end{tabular}

$\mathrm{IQR}$, inter quartile range; Min, minimum value; Max, maximum value; $\mathrm{PCV}$, packed cell volume; $\mathrm{HB}$, hemoglobin concentration; $\mathrm{RBC}$, total erythrocytes count; $\mathrm{WBC}$, total leucocytes count; $\mathrm{MCV}$, mean corpuscular volume; $\mathrm{MCH}$, mean corpuscular hemoglobin; $\mathrm{MCHC}$, mean corpuscular hemoglobin concentration.

Table 4. Serum biochemical reference interval juvenile Heterotis niloticus sampled from site 2 and site 3.

\begin{tabular}{|c|c|c|c|c|c|c|c|c|c|}
\hline Parameters & Mean & $\begin{array}{l}\text { Standard } \\
\text { Deviation }\end{array}$ & Mode & Range & IQR & $1^{\text {st }}$ Quantile & $3^{\text {rd }}$ Quantile & Min & Max \\
\hline $\begin{array}{l}\text { Glucose } \\
\text { (mg/dL) }\end{array}$ & 80.44 & 18.29 & 83.00 & 57.00 & 17.00 & 79.00 & 96.00 & 44.00 & 101.0 \\
\hline $\begin{array}{l}\text { Total Protein } \\
\text { (g/L) }\end{array}$ & 68.06 & 16.97 & $\begin{array}{l}63.0 \\
79.0\end{array}$ & 57.0 & 23.50 & 56.00 & 79.50 & 41.00 & 98.00 \\
\hline Globulin (g/L) & 13.72 & 1.83 & 16.00 & 5.50 & 3.29 & 12.31 & 15.60 & 10.50 & 16.00 \\
\hline Albumin (g/L) & 65.49 & 19.41 & $\begin{array}{l}23.00 \\
40.5 \\
49.1\end{array}$ & 62.90 & 33.05 & 48.10 & 81.15 & 23.00 & 85.90 \\
\hline AST (U/L) & 93.46 & 8.57 & $\begin{array}{l}103 \\
93\end{array}$ & 26.00 & 13.10 & 89.90 & 103.0 & 78.00 & 104.0 \\
\hline ALT (U/L) & 37.14 & 15.22 & $\begin{array}{l}16 \\
24.1\end{array}$ & 49.00 & 23.30 & 26.7 & 50.0 & 16.00 & 65.00 \\
\hline ALP (U/L) & 53.31 & 11.19 & 49.0 & 40.00 & 16.00 & 45.00 & 61.00 & 33.00 & 73.00 \\
\hline CRT ( $\mu \mathrm{mol} / \mathrm{L})$ & 70.92 & 9.194 & 69.74 & 34.00 & 13.50 & 64.00 & 77.50 & 53.00 & 87.00 \\
\hline UREA (mg/dL) & 15.02 & 2.79 & 13.6 & 8.17 & 4.50 & 13.00 & 17.5 & 11.23 & 19.40 \\
\hline $\mathrm{UA}(\mathrm{mg} / \mathrm{dL})$ & 2.55 & 0.50 & $\begin{array}{l}2.2 \\
2.3\end{array}$ & 1.60 & 0.80 & 2.2 & 3.00 & 1.80 & 3.40 \\
\hline
\end{tabular}

IQR, inter quartile range; Min, minimum value; Max, maximum value; AST, aspartate aminotransferase; ALT, alanine aminotransferase; ALP, alkaline phosphatase; CRT, creatinine; UA, uric acid.

Table 4 further shows the serum albumin concentration of these fishes to have a range of $5.50 \mathrm{~g} / \mathrm{L}$ with an interquartile range of $3.29 \mathrm{~g} / \mathrm{L}$. In addition, the mean serum alkaline phosphatase (ALP) activity is $53.31 \mathrm{U} / \mathrm{L}$ with minimum and maximum value of $33.0 \mathrm{U} / \mathrm{L}$ and $73.0 \mathrm{U} / \mathrm{L}$ respectively. The mean serum urea concentration for fish obtained from this site is $15.02 \mathrm{mg} / \mathrm{dL}$ with a range of $8.17 \mathrm{mg} / \mathrm{dL}$ and an interquartile range of $4.50 \mathrm{mg} / \mathrm{dL}$.

\section{DISCUSSION}

Hematological and serum biochemical assessments are valuable tools in the clinical decision-making processes; as changes in these values may be used as indicators of the presence or absence of disease processes, nutritional abnormalities or environmental inadequacies [17, 24, 25]. However, to arrive at a clinical decision based on hematology and serum biochemistry assessments, there is the need to 
establish species-specific data for the purpose of comparisons. Although there is a growing database of reference interval/ranges for several farmed fish species, there is however, a paucity of information on the hematology and serum biochemistry reference ranges for $\mathrm{H}$. niloticus. We could not separate the sampled fish along sex lines, as there were no distinctive external genitalia similar to the report in Arapaima gaigas [37, 38]. In this report, we present data obtained from 243 clinically healthy juvenile $H$. niloticus sampled from pristine locations in the Lower Benue River basin.

The packed cell volume (pcv) is one of the most common diagnostic tool used to evaluate the quantity of erythrocytes. This value (expressed as a percentage) represents the concentration of erythrocytes per unit volume of blood. Stress (handling, capture, increased activity levels), age/size of fish, and plain of nutrition as well as extrinsic factors (water temperature, dissolved oxygen concentration) have been reported to influence the packed cell volume in the blood of fishes. The pcv in teleost is reported to range from $20.0 \%$ to $45.0 \%$ [39]. In the present study, pcv of $H$. niloticus ranged from $17.0 \%$ to $33.0 \%$. Although, the values reported by [1] and [26] for $\mathrm{H}$. niloticus falls within this range, it is however lower than the range (31.0\% to $38.5 \%$ ) reported for Arapaima gigas [37]. The differences in the pcv ranges may be attributable to the species variation and or plane of nutrition, as the data in $A$. gigas were obtained from fish under intensive culture with a presumably better nutritional status.

The hemoglobin concentration is a measure of the hemoglobin contained per unit erythrocyte. It is a reflection of the oxygen carrying capacity of the erythrocytes. It is reported that the hemoglobin concentration in most fish species to range from 5.0 - $10.0 \mathrm{~g} / \mathrm{dL}$ [39]. In the present report, $H$. niloticus had a hemoglobin concentration with a range of $2.0-7.0 \mathrm{~g} / \mathrm{dL}$ with a calculated reference range of $3.1-6.4 \mathrm{~g} / \mathrm{dL}$. These values are similar to those reported for $\mathrm{H}$. niloticus sampled from Western Nigeria [26], but lower than values reported for Arapaima gigas [38].

The total erythrocytes counts is an estimate of the number of red blood cells present in a unit volume of blood. In the present report, the total erythrocytes count in $\mathrm{H}$. niloticus range from $1.59 \times 10^{6}$ to $2.92 \times 10^{6} \mu / L$ of blood. This range is not significantly different from values reported for $\mathrm{H}$. niloticus sampled from the Anambra River [27], but significantly higher than values reported for $A$. gigas [38]. The total leucocytes counts obtained for $H$. niloticus in this report ranges from 5.97 $\times 10^{3}$ to $5.40 \times 10^{3} \mu^{-1}$ of blood compared with $14 \times 10^{3} \mu / L$ to $18 \times 10^{3} \mu / L$ of blood reported in A. gigas [38].

The erythrocytic indices (mean corpuscular volume, mean corpuscular hemoglobin and the mean corpuscular hemoglobin concentration) are clinically relevant parameters derived mathematically from the values obtained for the total erythrocyte count, the packed cell volume and the hemoglobin concentration. Together, these values describe the nature and categories of anemias [33]. Montero et al., [39] reported the mean corpuscular volume (mcv) in teleost ranges from 150 to $350 \mathrm{fL}$ and the mean corpuscular hemoglobin (mch) ranges from 30 to $100 \mathrm{pg}$ while the mean corpuscular hemoglobin concentration (mchc) ranges from 18 to $30 \mathrm{~g} / \mathrm{dl}$. In the present study, the reference ranges obtained for $\mathrm{mcv}$ and mch are $102.75 \mathrm{fL}$ to $218.7 \mathrm{fL}$, and $13.32 \mathrm{pg}$ to $28.85 \mathrm{pg}$ respectively, while the mchc values range from 12.61 to $28.34 \mathrm{~g} / \mathrm{dl}$. The $\mathrm{mcv}$ values in this study are within the ranges reported for teleost, while the mch and mchc values are lower than those reported for teleost [39]. Further, the mcv ranges in this study is significantly higher compared with the range reported for $A$. gigas another obligate air breathing fish species [38]. The reason for this variation may be attributable to the effects of extrinsic factors (water temperature and dissolved oxygen content) and intrinsic factors such as species-specific variations (age, genotype and gender of the fish).

\subsection{Serum biochemistry}

Glucose is an important metabolic fuel needed for the proper functioning of energy dependent processes of the brain, heart, muscles, gut, gonads and the erythrocytes. Glucose is mobilized following perturbations in physiological and or environmental conditions $[40,41]$. In a review on carbohydrates metabolism in fishes [42] reported that increases in blood glucose concentration (termed hyperglycemia) occurs as a result of seasonal osmoregulatory changes, presence of stressors and or shifts in diets compositions, whereas decreases in blood glucose concentrations (termed hypoglycemia), are a product of food deprivations and or environmental perturbations (crowding stress and or hypoxia). In the present study, 51.00 to $89.5 \mathrm{mg} / \mathrm{dl}$ was obtained as the reference range for serum glucose concentration. This range is above the upper limits of those reported by [1] but like the values reported for $\mathrm{H}$. niloticus [26] and [27]. Further, these values are also lower than the range for serum glucose concentration reported for Arapaima gigas [38]. The variations in the serum glucose concentrations obtained in this study compared to the cited studies may be a result of the differences in carbohydrate metabolism, age differences and species variations in the various studies [42].

The serum total protein concentration provides a critical information reflecting the functional statuses of various organs and or systems $[32,43]$. The serum total proteins help maintain colloid osmotic pressure, serves as catalyst in biochemical processes [41] and plays a significant role in the production of fibrin polymers needed for blood clot formation 
[24]. Serum total protein concentration are increased in hemoconcentration and or dehydrations, and reduced in cases of malnutrition, hepathopathies and specific protein undernutrition $[41,44]$. The serum total protein concentration reported in $\mathrm{H}$. niloticus sampled from Anambra River [27] and from the South Western Nigeria [26] are within the reference ranges $(56.6$ to $79.5 \mathrm{~g} / \mathrm{L}$ ) obtained in the present study; these reference range is also similar to values reported in $A$. gigas [38].

Serum albumins are produced in the liver. Therefore, the synthetic capacity of the liver (which is an estimate of the protein losing nephropathy) may be estimated by the determination of the serum albumin concentration [44]. Reduced serum albumin concentration (termed hypoalbuminemia) is observed in situations of malnutrition, increased protein catabolism, enteropathy and in chronic nephropathy [41]. The 11.5 to $15.5 \mathrm{~g} / \mathrm{L}$ obtained as the serum albumin reference range in this study is in agreement with the values previously reported for $H$. niloticus [26, 27].

The hepatic enzymes (transaminases and alkaline phosphatase), are used routinely in clinical evaluation of disease processes [45]. These enzymes are synthesized in the liver and in hepatocellular or cholestatic liver injuries, these enzymes are liberated into the serum. In hepatopathies such as seen in hepatocellular degenerations, aspartate aminotransferase (AST) and alanine aminotransferase (ALT) are liberated in the serum; while alkaline phosphatase (ALP) is liberated into the serum in hepatic cholestasis [41, 45]. The pathogenesis of hepatic diseases in teleost are reported to be associated with viral hepatitis, parasitic infections and or mechanical injuries [40]. Further, due to the large functional reserves of the liver, hepatic failures may not become apparent up until $70 \%$ of the functional capacity of the liver is compromised [24]. In the present report, the AST values range from 51.9 to $104.0 \mathrm{U} / \mathrm{L}$ with a calculated reference range of 79.2 to $98.3 \mathrm{U} / \mathrm{L}$ while the ALT values range from 14.0 to $53.0 \mathrm{U} / \mathrm{L}$ with a calculated reference range of 24.78 to $46.0 \mathrm{U} / \mathrm{L}$. The reference range for ALP in this report is 28.75 to $57.25 \mathrm{U} / \mathrm{L}$. These values, except for the values of alkaline phosphatase are similar to the values reported for $H$. niloticus sampled from the Anambra River [27]. Further, the values obtained for AST, ALT and ALP are within the range of values reported for $A$. gigas a closely related facultative air breather [46].

Creatinine is an important moiety in muscle metabolism. Through the synthesis of phosphocreatinine, serum creatinine provides a storage for high-energy phosphates. Serum creatinine concentration is increased significantly by skeletal muscle necrosis and or atrophy as well as in chronic nephropathy [25]. In the present study, the reference range for serum creatinine is 51.0 to $80.0 \mu \mathrm{mol} / \mathrm{L}$ with minimum and maximum values of 43.0 and $89.0 \mu \mathrm{mol} / \mathrm{L}$ respectively. For the purposes of a comparative evaluation with the data obtained in the present study, we could not find previously reported values of serum creatinine concentrations in $\mathrm{H}$. niloticus. The range obtained for serum creatinine concentration in the present study is however consistent with the values reported for $A$. gigas a closely related fish species $[8,38]$.

Generated in the liver via the urea cycle, urea nitrogen is the product of protein and or amino acids metabolism. The blood urea nitrogen is a critical tool in the clinical assessments of renal function [25]. Decreased blood urea nitrogen concentrations is observed in hepatic insufficiencies and in cases of malnutrition while increased blood urea nitrogen concentration is commonly reported in renal disease, shock and in cardiac insufficiencies [47]. Uric acid is a waste product of purine metabolism that plays a role in several biological processes. Uric acid is both a powerful antioxidant, which under specific conditions serves as a pro-oxidant giving rise to an increase in free radicals, endothelial vascular dysfunction and changes in nitric oxide production. Serum uric acid concentrations are an easily available and cheap markers of several co-morbidities associated with cardiovascular diseases [25]. The reference range obtained for urea nitrogen and uric acid in the present study are $1.90 \mathrm{mg} / \mathrm{dL}$ to $2.30 \mathrm{mg} / \mathrm{dL}$ and 13.1 $\mathrm{mg} / \mathrm{dL}$ to $17.1 \mathrm{mg} / \mathrm{dL}$ respectively. In addition, as mentioned for creatinine, there are no reported data or reference ranges for these analytes in $H$. niloticus. However, a comparison of the data obtained in the present study with that reported for $A$. gigas shows there are no variations in the values obtained for urea nitrogen and uric acid in these two related facultative air breathing fish species.

The results obtained for the hematological and serum biochemical assessments from sampling site 2 (discharge of Wase river into River Benue), were not significantly different from those obtained from site 3 (discharge of Mada river into River Benue). The reason for this may be a result of the absence of agricultural activities in these two sites. Hence, it can be deduced that the values obtained in fishes sampled from site 1 may be a result of stress following the exposure of the fishes to agricultural chemicals and other anthropogenic perturbations that may be present in these sites. Results obtained from sites 2 and 3 were therefore, collated as results from a single site. Further, the results obtained for sampling site 1 and the other two sampling sites (i.e. sampling sites $2 \& 3$ ) reveals there were no variations in the values obtained for hemoglobin concentration, total leucocytes count and the Mean corpuscular volume (MCV). These values are $2.00 \mathrm{~g} / \mathrm{dL}$ to 7.40 $\mathrm{g} / \mathrm{dL}, 4.80 \times 10^{3} \mu / \mathrm{L}$ to $6.31 \times 10^{3} \mu / \mathrm{L}$ and $102.1 \mathrm{fl}$ to $265.6 \mathrm{fl}$ respectively. While the ranges obtained for packed cell volume (PCV), total erythrocytes counts, mean corpuscular hemoglobin 
$(\mathrm{MCH})$ and mean hemoglobin concentration $(\mathrm{MCHC})$ are $17.0 \%$ to $33.0 \% ; 0.64 \times 10^{6} \mu / \mathrm{L}$ to $4.10 \times 10^{6} \mu / \mathrm{L} ; 23.70 \mathrm{Pg}$ to $30.91 \mathrm{Pg}$ and $11.77 \mathrm{~g} / \mathrm{dL}$ to $30.90 \mathrm{~g} / \mathrm{dL}$ respectively.

As was observed in the hematological results, there were no variations in the values obtained for some serum biochemical parameters namely: serum globulin concentration, albumin concentration and uric acid concentration in comparisons of sampling site 1 and sampling sites 2 and 3 . Hence, the reference ranges for serum globulin, albumin and uric acid concentration are $9.00 \mathrm{~g} / \mathrm{L}$ to $16.10 \mathrm{~g} / \mathrm{L} ; 23.00 \mathrm{~g} / \mathrm{L}$ to $86.8 \mathrm{~g} / \mathrm{L} ; 1.80 \mathrm{mg} / \mathrm{dL}$ to $3.40 \mathrm{mg} / \mathrm{dL}$ respectively.

The reference ranges for serum glucose and serum total protein concentration are $35.0 \mathrm{mg} / \mathrm{dL}$ to $109.0 \mathrm{mg} / \mathrm{dL}$ and 39.0 $\mathrm{g} / \mathrm{L}$ to $103.0 \mathrm{~g} / \mathrm{L}$ respectively. While the reference ranges for serum activities of aspartate aminotransferase, alanine aminotransferase, alkaline phosphatase, serum creatinine and serum urea concentrations are; $51.9 \mathrm{U} / \mathrm{L}$ to $104.0 \mathrm{U} / \mathrm{L} ; 14.0 \mathrm{U} / \mathrm{L}$ to $65.0 \mathrm{U} / \mathrm{L} ; 10.0 \mathrm{U} / \mathrm{L}$ to $73.0 \mathrm{U} / \mathrm{L} ; 43.0 \mu \mathrm{mol} / \mathrm{L}$ to $89.0 \mu \mathrm{mol} / \mathrm{L}$ and $11.23 \mathrm{mg} / \mathrm{dL}$ to $19.40 \mathrm{mg} / \mathrm{dL}$ respectively.

The reference values obtained in the present study could not be defined in the line of gender as the sampled $\mathrm{H}$. niloticus could not be identified as males or females due to the absence of distinct external genitalia for either sex as was previously reported in Arapaima gigas a related ostheoglossiform fish. Further, due to a paucity of health data for $\mathrm{H}$. niloticus, the results obtained in this study were vigorously compared with results reported for Pirarucus (Arapaima gigas Schinz, 1822) the only other extant osteoglossiform fish for which has been established hematology and serum biochemical reference intervals [38].

\subsection{Conclusions}

In this study, we present the haematological and serum biochemical reference ranges for Heterotis niloticus sampled from the Benue River Basin. The application of this data set may aid in the accelerated resolution of the etiologies of mortalities encountered in previous attempts at the culture of this fish species and the prognostication of the effects of management/conservation efforts of $H$. niloticus in freshwater fisheries of Nigeria.

\section{Acknowledgment}

The authors are thankful to Ms. Nancy Atsua (our local guide to the fishing sites and communities) and to Mr. John Ochete, Richard Oguche and Paulinus Idachaba for their technical support in fish catching and handling.

\section{Conflict of interest}

The authors declare no conflict of interest.

\section{REFERENCES}

[1]. Fagbenro OA, Adedire CO, Ayotunde EO. Haematological profile, food composition and digestive enzyme assay in the gut of the African bonytongue fish, Heterotis (Clupisudis) niloticus (Cuvier 1989) (Osteoglossidae). Trop Zool 2000;13:1-9. https://doi.org/10.1080/03946975.2000.10531125

[2]. FAO Inland Water Resources and Services, Fishery Resources Division. Review of the state of world fishery resources: Inland fisheries. Food and Agriculture Organization Fisheries Circular 2003; No. 942: 1-60.

[3]. Akegbejo-Samsons FO, George A, Agbon AO. Growth, reproduction and aquaculture potential of the African bonytonque fish ( $H$ niloticus) in ponds and reservoirs in coastal south-west states of Nigéria. In: International Conference of the Panafrican Fish and Fisheries Association, Cotonou, Benin 2003;10-14 November.

[4]. Pauly D. Some simple methods for the assessment of tropical fish stocks. FAO Fisheries Technical Paper, (234), FAO Rome, Italy 1983.

[5]. Adite A, Winemiller KO, Fiogbe ED. Population structure and reproduction of the African bonytongue Heterotis niloticus in the Sô River-floodplain system (West Africa): implications for management. Ecol. of Freshwater Fish 2006; 15: 30-39. https://doi.org/10.1111/j.1600-0633.2005.00119.x

[6]. Monentcham SE, Kouam J, Pouomogne V, Kestemont P. Biology and prospect for aquaculture of African bonytongue, Heterotis niloticus (Culvier, 1829): a review. Aquaculture 2009;289: 191-198. https://doi.org/10.1016/j.aquaculture.2009.01.019

[7]. Ferraris CJ (Jr). Family Arapaimatidae (bonytongues). In: Reis, R.E., Kullander, S.O., and Ferraris, C.J. Jr., (Eds.). Check list of the freshwater fishes of South and Central America. Porto Alegre, Brazil: EDIPUCRS, 2003; pp. 31.

[8]. Guo-Qing L, Wilson MVH. Phylogeny of Osteoglossomorpha. In: Stiassny, M.L.J., Parenti, L.R. \& Johnson, G.D. (Eds.). Interrelationships of fishes. San Diego, CA: Academic Press, 1996; pp. 163-174. https://doi.org/10.1016/B978-012670950-6/50009-6

[9]. Adite A, Ediye MM, Toko II, Abou Y, Youssouf A, Imorou RS, Sonon SP. Morphological and meristic Characterization of the African bonnytongue, Heterotis niloticus (Cuvier, 1829), from lake Hlan and So River, Southern Benin, West Africa; The need for habitat protection and species conservation. Int J Fish Aqua Res 2017;2: 16-28

[10]. Hurtado LA, Carrera E, Adite A, Winemiller KO. Genetic differentiation of a primitive teleost, the African bonytongue Heterotis niloticus, among river basins and within a floodplain river system in Benin, West Africa J Fish Biol 2013; 83: 682-690. https://doi.org/10.1111/jfb.12198

[11]. Bake GG, Sadiku SOE. Food and Feeding habits of Heterotis niloticus from river Kaduna flood plain. Proceding of the Annual conference of the fisheriesn society of Nigeria (FISON) 2002; p. 511-514.

[12]. Monentcham SE, Pouomogne V, Kestemont P. Influence of dietary protein levels on growth performance and body composition of African bonny tongue fingerlings, Heterotis niloticus (Cuvier, 1829). Aquaculture Nutrition 2010; 16: 144-152. https://doi.org/10.1111/j.13652095.2008.00646.x

[13]. Ugwumba AAA. The food and feeding habits of Heterotis niloticus (Teleostei: Osteoglossidae) in a small tropical man-made lake in Ibadan, Nigeria. J Afri Zool 1992;106: 113-123. https://doi.org/10.1007/BF00020823

[14]. Adeyemo BT, Obande RA, Solomon GS. Haematological reference ranges of cultured Clarias gariepinus in the lower Benue River Basin. J Comp Clin Pathol 2014; 23: 361-366. http://doi.org/10./007s00580-012-1624-1

[15]. Tripathy NK, Latimer KS, Burnley VV. Haematologic reference intervals for koi (Cyprinus carpio), including blood cell morphology, cytochemistry and ultra-structure. Vet Clin Path 2004;33: 7483https://doi.org/10.1111/j.1939-165X.2004.tb00353.x 
[16]. Tavares-Dias M, Moraes FR (2007). Haematological and biochemical reference intervals for farmed channel catfish. J. of Fish Biol. 71: 383-388. https://doi.org/10.1111/j.1095-8649.2007.01494.x

[17]. Clauss T, Dove A, Arnold J. Hematological disorders of fish. The Veterinary Clinics of North America Exotic Animal practice 2008;11: 445-462. https://doi.org/10.1016/j.cvex.2008.03.007

[18]. Witeska M, Lugowska K, Kondera E. Reference values of hematological parameters for juvenile Cyprinus carpio. Bull. Eur Ass Fish Pathol 2016;36: 169-180

[19]. Ambbayya A, Su AT, Osman NH, Nik-Samsudin NR, Khalid K, Chang MK, Sathar J, Rajasuriar SJ, Yegappan S. Hematological reference intervals in a multiethnic population. PloS ONE 2014;9: e91968. https://doi.org/10.1371/journal.pone.0091968

[20]. Luskova V. Determination of normal values in fish. Acta Universitas Carolinae Biologica 1995; 39: 191-200

[21]. Borges A, Scotti LV, Siqueira DR, Jurinitz DF, Vassermann GF. Hematological and serum biochemical values for jundia (Rhamdia quelen). Fish Physiol Bioch 2004; 30:21-25. https://doi.org/10.1007/s10695-0045000-1

[22]. Owolabi OD . Hematological and serum biochemical profile of the upsidedown catfish Synodontis membranacea Geoffroy Saint Hilarre from Jebba Lake, Nigeria. Comp Clin Pathol 2011; 20: 163-172. https://doi.org/10.1007/s00580-010-0973-x

[23]. Hrubec TC, Cardinale JL, Smith SA. Haematology and Plasma Chemistry Reference Intervals for Cultured Tilapia (Oreochromis Hybrid). Vet Clin Pathol 2000; 29: 7 -12. PMID: 12070816 DOI: 10.1111/j.1939165x.2000.tb00389.x

[24]. Peres H, Costas B, Perez-Jimenez A, Guerreiro I, Oliva-Tele A . Reference values for selected haematological and serum biochemical parameters of Senegalese sole (Solea senegalensis Kaup, 1858) juveniles under intensive aquaculture conditions. J Appl Ichthyol 2015; 31: 65-71. https://doi.org/10.1111/jai.12641

[25]. Stoskopf MK . Clinical Pathology in Fish Medicine. WB Saunders Company,New York, USA., 1993;251pp.

[26]. Ayotunde EO, Fagbenro AO, Offem BO. Haematological characteristics of African bony tongue, Heterotis niloticus (Teleostei: Arapaimidae), in South-Western Nigeria. Afr J Aqua Sci 2009;34: 97-101. https://doi.org/10.2989/AJAS.2009.34.1.10.735

[27]. Odo GE, Nwamba HO, Eyo JE. Aspect the biology of Heterotis niloticus Curvier 1829 (Osteoglossiformes: Osteoglossidae) in the Anambra flood River system, Nigeria. Animal Research International 2009; 6: 994-1002. https://doi.org/10.4314/ari.v6i2.48131

[28]. Neiffer DL, Stamper MA (2009). Fish sedation, anesthesia, analgesia and euthanasia: considerations, methods and types of drugs. ILAR J 2009; 50 : 343-360. https://doi.org/10.1093/ilar.50.4.343

[29]. Roberts HE. Physical examination of fish. In: Roberts H E (Ed.). Fundamentals of ornamental fish health. Ames (IA): John Wiley and Son; 2010; $p$ 161-165.

[30]. Boyd CE, Tucker CS. Water quality and pond soil analysis for aquaculture. Agricultural experiment station, Auburn University, Auburn. Alabama, USA. 1992; pp. 183.

[31]. Campbell TW. Haematology of fish. In: Thrall, M.A., Weiser, G., Allison, R., (Eds.). Veterinary Haematology and clinical chemistry. Ames (IA): John Wiley and Sons.2012; pp. 293-312.

[32]. Knowles S, Hrubec TC, Smith SA, Bakal RS. Haematology and plasma chemistry reference intervals for cultured short Nose Sturgeon (Acipenser brevirostrum). Vet Clin Pathol 2008;35: 434- 440. https://doi.org/10.1111/j.1939-165X.2006.tb00160.x

[33]. Campbell TW. Haematology of fish. In Troy D.B (Ed.), Veterinary haematology and Clinical Chemistry. Baltimore: Lippincott. Williams and Wilkins. pp. 2004;277-289.

[34]. Linnet K . Non-parametric estimation of reference intervals by simple and bootstrap-based procedures. Clin Chem 2000;46: 867-869. https://doi.org/10.1093/clinchem/46.6.867
[35]. NCCLS (National Committee for Clinical Laboratory Standards). How to define, determine and utilize reference intervals in the clinical laboratory; proposed guidelines. Document C 28-P. NCCLS, Villanova, Pennsylvania. PMID 1992; 1497442

[36]. Friedrichs KR, Harr KE, Freeman KP, Szladovits B, Walton RM, Barnhart KF, Blanco-Chavez, J. ASVCP reference interval guidelines: determination of de novo reference intervals in veterinary species. Vet Clin Pathol 2012;41: 441-453. https://doi.org/10.1111/vcp.12006

[37]. Dugue R, Chu Koo F, Alancantara F, Duponchelle F, Renno JF, Nunez J. Purification and assay of Arapaima gigas vitellogenin: potential use for sex determination. Cybium 2008;32: 111- 119

[38]. Tavares-Dias M, Barcellos JFM, Macron JL, Menezes GC, Ono EA, Affonso EG . Haematological and biochemical parameters for the Pirarucu Arapaima gigas Schinz, 1822 (Osteoglossoformes, Arapaimatidae) in net cage culture Elect J Ichth 2007; 2: 61-68

[39]. Montero D, Izquierdo MS, Tort L, Robaina L, Vergara JM . High stocking density produces crowding stress altering some physiological and biochemical parameters in gilthead seabream, Sparus aurata, juveniles. Fish Physiol Biochem 1999;20: 53-60.

[40]. Hrubec TC, Smith SA . Hematology of fishes. In: Weiss D.J, Wardrop K.J (Eds.). Schalm veterinary hematology. Ames (LA): John Wiley and Sons 2010; p. 994-1003.

[41]. Wagner T, Congleton JL. Blood chemistry correlates of nutritional condition, tissue damage, and stress in migrating juvenile chinook salmon (Oncorhynchus tshawytscha). Can J Fish Aquat Sci 2004; 61: 1066-1074. https://doi.org/10.1139/f04-050

[42]. Polakof S, Panserat S, Soengas $\amalg$, Moon TW. Glucose metabolism in fish: areview. J of Comp Physiol 2012;B 182: 1015-1045. https://doi.org/10.1007/s00360-012-0658-7

[43]. Wells RMG, Pankhurst NW. Evaluation of simple instruments for the measurement of blood glucose and lactate, and plasma protein as stress indicators in fish. J World Aquacult Soc 1999;30: 276-284. https://doi.org/10.1111/j.1749-7345.1999.tb00876.x

[44]. McCue MD . Starvation physiology; reviewing the different strategies animals use to survive a common challenge. Comp Biochem Physiol 2010;156: 1-18. https://doi.org/10.1016/j.cbpa.2010.01.002

[45]. Lemarie P, Drai P, Mathieu A, Lemaire S, Carriere S, Giudicelli S, Lafaurie $M$. Changes with different diets in plasma enzymes (GOT, GPT, LDH, ALP) and plasma lipids (cholesterol, triglycerides) of sea-bass (Dicentrarchus labrax). Aquaculture 1991; 93: 63-75. https://doi.org/10.1016/00448486(91)90205-L

[46]. Bezerra RF, Soares MCF, Santos AJG, MMaciel-Carvalho EV, Coelho LCBB. Secondary indicators of seasonal stress in the Amazonian pirarucu fish (Arapaima gigas)," in advances in Environmental Research, J. A Daniels (Ed.) 2013; 28, pp 233-244 Nova Science Publishers, New York, NY, USA.

[47]. Waisbren SE, Gropman AL. Improving long-term outcomes in urea cycle disorders. J. of Inherit Metab. Dis 2016;39: 573. DOI: https://doi.org/10.1007/s10545-016-9942-0 